\title{
PILOTING A TEACHER COMPETENCE MANAGEMENT MODEL IN SCHOOLS
}

\author{
Anete Butkēviča \\ University of Latvia, Latvia \\ Līga Čakāne \\ University of Latvia, Latvia \\ Inese Dudareva \\ University of Latvia, Latvia \\ Dace Namsone \\ University of Latvia, Latvia
}

\begin{abstract}
Compulsory education curriculum reform will introduce teaching $21^{\text {st }}$ century skills bringing in significant changes to how teacher work happens in Latvia. This highlights the role of school teams to plan not only whole-school development but also teacher personalized professional development to implement necessary changes. This research presents a schoolbased comparative case study for piloting a teacher competence management model that is created by the authors. The model represents the interaction of goal setting and competence management in organizations and this research paper is emphasizing parts of the model related to teacher competence assessment and development done at the school. 8 schools participated in the piloting in school year 2018/19. The comparative case study in spring semester 2019 happened through gathering and analysing data such as written reports and working documents from school teams. In this research paper we aim to introduce the reader about the four phases of the model and the piloting process and results of the fourth phase - competence development. This paper presents a research project still in progress and will seek ways how such a model may be implemented in schools.
\end{abstract}

Keywords: Teacher competence management, Teacher assessment, Comparative case study, $21^{\text {st }}$ century skills.

\section{Introduction}

A new compulsory education curriculum reform is being developed and is planned to be implemented in Latvian school practice with school 
year 2020/2021 (Namsone, 2018; Skola2030, 2017). The reform is aiming to set new educational goals such as implementing student learning that leads to acquiring $21^{\text {st }}$ century skills which is a widespread educational change in other countries (Care, Griffin, \& Wilson, 2017). With changing educational purposes, teachers' instructional work at the individual level must also change accordingly, which imply important human capital implications including those related to teacher professional development and learning (Saavedra \& Opfer, 2012). Previous research in Latvia has already showed that there is a gap between educational policy and actual teaching approaches in the classroom (France, Namsone, \& Čakāne, 2015; Volkinšteine \& Namsone, 2016). Despite $21^{\text {st }}$ century skills being set as a particularly important aspect of innovation-intensive labour markets, consensus does not yet exist on how education systems should develop and assess teaching of these skills systematically (OECD, 2015).

In the Latvian context, up to date research-based evidence showing that teachers are equipped with the necessary competence and appropriate support in the context of these curriculum changes is limited. Educational researchers in Latvia have been focusing on topics such as in-service and pre-service teacher professional identity (Ivanova \& Skara-Mincāne, 2016; Jermolajeva, Bogdanova, \& Silchenkova, 2018), pre-service teachers (Daniela, Strods, Rubene, \& Kalnina, 2018), formation of teacher professional learning communities (Geske \& Rečs, 2019) or school principals (for a review see Bluma \& Daiktere, 2016). To our knowledge, in the context of new education changes such as teaching and learning $21^{\text {st }}$ century skills there have not been empirical research on new approaches to teacher as employee competence management that would be school-based and with direct involvement from the school leaders.

Our previous empirical research on creating and piloting a teacher professional learning model in Latvian schools, proved the usefulness of continues, collaborative school-based PD as a way to develop teacher competence or parts of it (Namsone \& Čakāne, 2019). In regards to the current state of teacher professional development in Latvia, large majority of teachers (95\%) participate in PD in the form of courses and seminars, while $61 \%$ participate in training based on peer learning and coaching (OECD, 2019) proving the need to widen the PD practice that would be practice-based and done together with school leaders in the school site.

In this article we outline the procedure and results from the first piloting of a teacher competence management model (Zandbergs, et al., 2018) in selected schools e.g. cases (initial sample $N=8$ ) that happened in the spring semester of 2019. This is done to gain insight of the model's applicability to be transferred and introduced in a wider school practice. 


\section{Background}

Teachers and school leaders should facilitate, create and stimulate conditions for effective instruction at classroom level that is the operating core of any school (Scheerens, 2016, p. 77). According to Jaap Scheerens, Dutch educational and school effectiveness researcher, empirical school effectiveness research show that the following organizational conditions are the main effectiveness enhancing variables: school climate (achievementoriented policy, a cooperative atmosphere and an orderly climate), clear goals concerning basic skills, frequent evaluations and time on task. Among other effectiveness enhancing factors are professional development, evaluation and reports for teachers (Scheerens, 2016, p. 97) and effective leadership (Scheerens, 2016, p. 78-79) therefor we include school leaders to participate in the piloting and learn about the model and its implementation in their own practice. Lastly, monitoring and evaluation should not happen in a way that it threatens teachers' professional autonomy (Scheerens, 2016, p. 81).

Following up on our previous research (Zandbergs, et al., 2018; Butkēviča, et al., 2018; Butkēviča, 2018; Butkēviča et al., 2019; Bērtule et al., 2019) we propose a teacher competence management model as an approach to help teachers and school leaders answer to the new challenges brought by the education curriculum reform and implement teaching and learning appropriate for students to acquire $21^{\text {st }}$ century skills. The model outlines the management of employee competence within the organization and this article looks into the parts of the model that are more related with competence development. In our research teacher competence is defined as the integrated set of knowledge, skills and beliefs that manifest in a specific work situation (Kunter et al., 2013).

Even though organizations in Latvia tend to have established procedures for goal-setting and employee assessment, managers in organizations, including schools, use subjective approaches when managing goals and assessing employee competence. Based on our previous research findings, we propose that using competence as a building block describing both employees themselves and the goals they are required to reach provides organizations with several benefits. It makes the definition of the goals more precise and aligns better with the organization's employees. It allows for better forecast of reaching the goals at the start of the cycle. It potentially provides the organizations with the input for the improvement of goal-oriented employee development (Butkēviča, et al., 2018). When linking employee competence to organizational goals, managers can act upon employee competence gaps that may be identified at the start of a goal setting period or during it. This is related to our model's first phase 
(see figure 1). Introducing an ontology-based model of linking goals to employee competences also provides the basis for developing a competence management model (Zandbergs, et al., 2018) and in this research stage we are piloting the model in school practice (formal education organization) to gain insight of its applicability to be transferred and introduced in these types of organizations.

In autumn semester 2018, outside expert-coaches started the comparative case study in eight selected schools. The eight pilot schools, participating in the whole project (period 2018-2021) were selected based on three criteria: 1) size as management workload rate and number of students, six groups (very small to very large) were identified and four of them are represented in this sample; 2) different administratively territorial division, five groups identified, all of them represented in this sample; 3) type of education programme provided by a school, seven groups identified, five of them represented in this sample (for a more detailed description see our previous research (Butkēviča, et al., 2018, 132).

Aim of the study in selected schools was to develop a teacher performance assessment framework for teaching $21^{\text {st }}$ century skills that help determine teacher level of competence (scale 0-4) according to criteria developed (Bērtule, et al., 2019).

Teacher knowledge and beliefs (as part of competence construct) were assessed by using an online test with questions such as given classroom situations asking the teacher to tell what their typical action in those situations would be (Butkēviča, et al., 2019). Teacher classroom performance was assessed by lesson observations. Both assessment methods are based on the mentioned framework.

In the piloting, a model of competence management process is used, with four phases, where the initial phase is goal setting and final phase is teacher competence development therefor linking these processes with competence assessment. Our previous research shows that this link between goal setting and competence assessment and development in Latvian organizations including schools is missing (Butkēviča, et al., 2018). Each phase has a distinct form of process and its outcome (see figure 1) that the participating schools followed through. The first three phases will be shortly explained in the next chapter and the fourth phase in results chapter. 


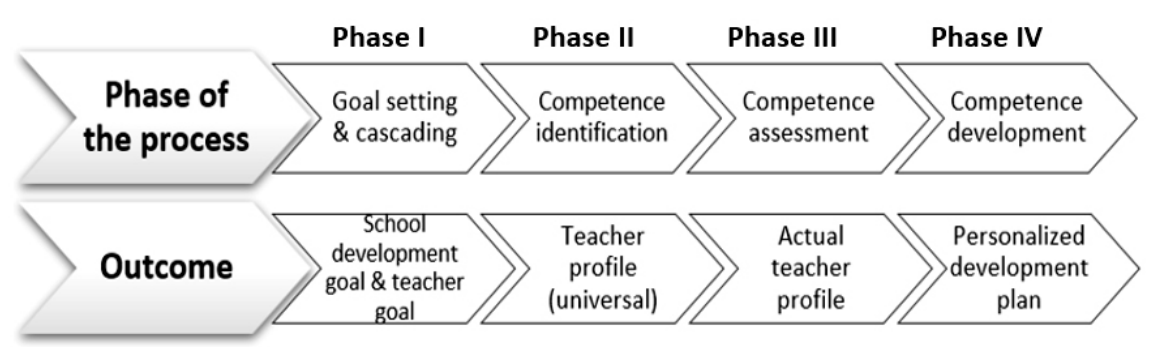

Figure 1. Phases of the competence management process and their outcomes (Butkēviča, et al., 2019)

Planning and implementation of piloting the teacher competence management model in selected schools $(\mathrm{N}=8)$ happens over a longer period of time. In this research paper we aim to introduce the reader about the four phases of the model and the piloting process and results of the fourth phase - competence development. We compare the piloting schools as separate cases and make conclusions about the trends of how participating school teams are leading such a model, and what may be the risks and benefits of its implementation in wider school practice. Following research questions are posed:

1. To what extent did the schools succeed in implementing the teacher competence development plan?

2. What are the best practices done in schools when piloting the teacher competence management model?

3. What are the main challenges for schools and expert-coaches when piloting the introduction of the model into school practice?

\section{Materials and Methods}

Five expert-coaches from Interdisciplinary Centre for Educational Innovation at the University of Latvia (ICEI UL) collaborated with pilot schools throughout the piloting (school year 2018/2019). The expertcoaches have been involved in seven to 17 years of experience in designing and leading different types of teacher and school leader professional development and learning activities as well as developing teacher support materials (Namsone \& Čakāne, 2018).

In Phase I (see figure 1) schools set their goals according to their own choice which happened in autumn semester, 2018. The goals are directly linked to student learning in the classroom related to teaching and learning $21^{\text {st }}$ century skills (see table 1 ). 
Table 1. Goals set by participating schools

\begin{tabular}{|l|l|}
\hline \multicolumn{1}{|c|}{ School } & \multicolumn{1}{|c|}{ Goal set by the school [summary] } \\
\hline 01_V & Unified approach for student evaluation \\
\hline 08_Z & Student self-directed learning \\
\hline 07_N & Student self-directed learning \\
\hline 02_U & Improving textual literacy for students through teacher collaboration \\
\hline 04_S & Student self-directed learning \\
\hline 06_P & Student self-directed learning \\
\hline 03_T & Improving different elements of student self-directed learning \\
\hline 05_R & $\begin{array}{l}\text { Lessons focused on students' learning result and their in-depth } \\
\text { understanding of learning }\end{array}$ \\
\hline
\end{tabular}

In Phase II (see figure 1) competence identification happens. Involved expert-coaches identify the needed and appropriated teacher competence profiles according to the goals set in each school. A universal teacher profile for each teacher is created and it consists of selected categories and criteria on desirable level (scale 0-4) based on a theoretical categorycriteria framework for teaching performance to develop $21^{\text {st }}$ century skills (Bērtule et al., 2019) (see table 2).

Table 2. Phase II Competence identification: teacher universal and actual profile (example)

\begin{tabular}{|c|c|c|c|c|c|c|}
\hline \multirow{2}{*}{ 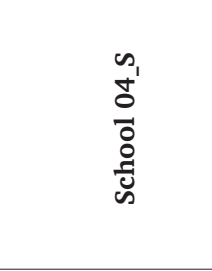 } & \multicolumn{3}{|c|}{$\begin{array}{l}\text { Accordance to school goal: } \\
\text { Student self-directed learning }\end{array}$} & \multicolumn{3}{|c|}{ Teacher basic skills } \\
\hline & $\begin{array}{c}\begin{array}{c}\text { Clarity } \\
\text { of } \\
\text { learning } \\
\text { goals }\end{array}\end{array}$ & $\begin{array}{l}\text { Feed- } \\
\text { back }\end{array}$ & $\begin{array}{l}\text { Meta- } \\
\text { cognitive } \\
\text { skills }\end{array}$ & $\begin{array}{l}\text { Structure } \\
\text { of the } \\
\text { lesson; } \\
\text { choice of } \\
\text { methods }\end{array}$ & $\begin{array}{l}\text { Methodo- } \\
\text { logical } \\
\text { techniques, } \\
\text { classroom } \\
\text { management }\end{array}$ & $\begin{array}{l}\text { Clarity } \\
\text { of } \\
\text { chosen } \\
\text { learning } \\
\text { content }\end{array}$ \\
\hline $\begin{array}{l}\text { Universal } \\
\text { profile** }\end{array}$ & 3 & 3 & 3 & 2 & 2 & 2 \\
\hline $\begin{array}{l}\text { Actual profile* } \\
\text { Teacher S_64 }\end{array}$ & 2 & 4 & 2 & 3 & 3 & 3 \\
\hline $\begin{array}{l}\text { Actual profile* } \\
\text { Teacher S_73 }\end{array}$ & 1 & 1 & 1 & 2 & 1 & 1 \\
\hline
\end{tabular}

*(scale 0-4)

In Phase III (see figure 1) competence assessment is done through lesson observation and by analysing the lessons. This is how actual teacher profile is obtained. Expert-coaches are involved to assess participating teachers' actual competence where the assessment result is each teachers' actual 
profile (see table 2) submitted to the school leaders. Phase II and III helps to recognize the teacher competence gap - difference between expected competence level (competence level needed to reach goals that are set) and the actual level. If necessary, schools can conduct their own assessments by using rubrics with descriptions of teacher performance levels created for the Latvian educational context (Bērtule, et al., 2019; Namsone, 2018).

In spring semester of 2019, the study in selected schools continues with the piloting of the teacher competence management model (see figure 1), more specifically, the model's fourth phase - competence development. This started at the beginning of January, 2019 with a joint workshop with leaders (principal with assistant principal) from each school and expertcoaches (see table 4). School leaders were introduced more in detail to the teacher competence management model. Then the following month, schools had time to form teams of teachers and deciding on their desired way of participating in the piloting. In the piloting, school leaders are given teacher assessment results (done and gathered from the previous semester by expert-coaches). Then schools received instructions for how to realize this competence development plan (see figure 2), rubrics with descriptions of teacher performance level and expert-coaches visited schools and did individual support sessions.

In Phase IV the expectation of the piloting is that school teams make teacher individual development plans and follow the next steps with the aim to minimize the mentioned competence gap. In the competence development, text in italics indicates examples, such as 'Assessment Method' may be a test, in our case it was lesson observation after which the next steps follow (see figure 2). With this phase the competence development continues until teacher universal and actual profile matches in so allowing the school to reach the set goal. Schools formed teams of teachers and school leaders who participated in the piloting.

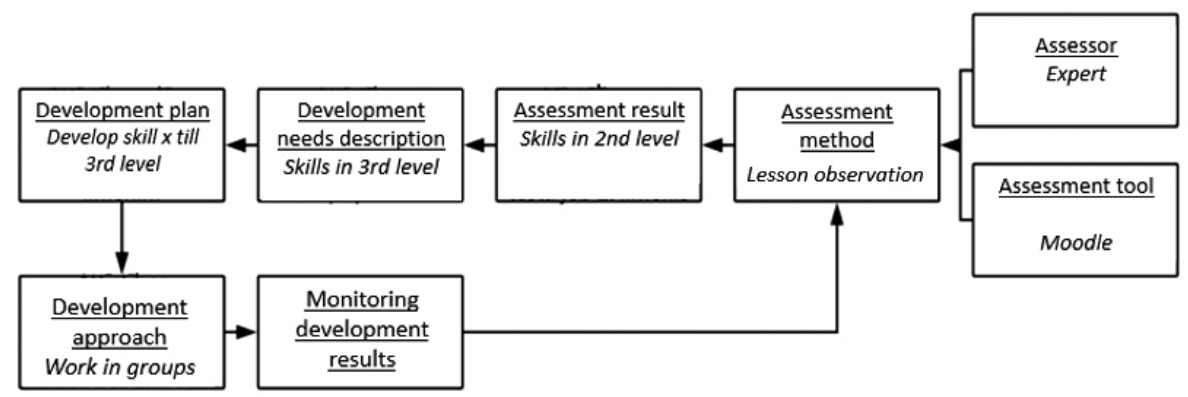

Figure 2. Competence development elements and their relationship (Phase IV) 
Lastly, in June schools submitted written reports on their piloting experience based on the following criteria:

- Activities, events organized with the school teams

- Developments / improvements that school teams accomplished

- Obstacles that school teams faced

- Support needs

- Planned activities for next school year

- Involved teachers, other colleagues from the school (see table 3).

Table 3. Number of involved teachers and school leaders

\begin{tabular}{|c|c|c|}
\hline School & Number of involved teachers & Number of involved school leaders \\
\hline $08 \_Z$ & 18 (all school teachers) & 2 \\
\hline $07 \_N^{*}$ & - & - \\
\hline $02 \_U$ & 15 to 20 & 2 \\
\hline $04 \_S$ & 22 (all school teachers) & 4 \\
\hline 06_P & 6 & 3 \\
\hline 03_T & 5 & 2 \\
\hline 05_R & 7 & - \\
\hline 01_V*** & - & 2 \\
\hline
\end{tabular}

*Full report was not submitted

$\approx *$ The school stopped participation in piloting

Expert-coaches interpreted the results. The reports are prepared by the assigned teacher team leader who also takes an administrative position in the school therefor in this research we analyse the competence development process from the school administration teams' point of view.

Table 4. Summary of support activities during piloting

\begin{tabular}{|c|l|l|}
\hline \multicolumn{1}{|c|}{ Date } & \multicolumn{1}{|c|}{ Activity } & \multicolumn{1}{c|}{ Aim of the activity } \\
\hline $\mathbf{0 4 . 0 1 . 2 0 1 9}$ & $\begin{array}{l}\text { Joint workshop with school } \\
\text { administrative teams }\end{array}$ & $\begin{array}{l}\text { Introduction to the piloting goal, } \\
\text { logic, possible ways how to } \\
\text { participate in it }\end{array}$ \\
\hline $\mathbf{0 4 - 2 9 . 0 1 . 2 0 1 9}$ & $\begin{array}{l}\text { Schools forming teams of } \\
\text { teachers, setting out desired } \\
\text { ways of participation }\end{array}$ & $\begin{array}{l}\text { Collect reports from schools to } \\
\text { understand in what scale and } \\
\text { format schools want to participate }\end{array}$ \\
\hline $\mathbf{2 9 . 0 1 . 2 0 1 9}$ & $\begin{array}{l}\text { Sending out instruction to } \\
\text { school teams }\end{array}$ & $\begin{array}{l}\text { School teams have unified } \\
\text { instructions to guide the piloting }\end{array}$ \\
\hline $\mathbf{0 1 - 2 8 . 0 2 . 2 0 1 9}$ & $\begin{array}{l}\text { Expert-coaches visiting } \\
\text { schools, electronical contact }\end{array}$ & $\begin{array}{l}\text { Face to face contact between } \\
\text { school teams and expert-coaches, } \\
\text { individual support }\end{array}$ \\
\hline
\end{tabular}




\begin{tabular}{|c|l|l|}
\hline \multicolumn{1}{|c|}{ Date } & \multicolumn{1}{|c|}{ Activity } & \multicolumn{1}{c|}{ Aim of the activity } \\
\hline 01-28.06.2019 & $\begin{array}{l}\text { Schools prepare reviews about } \\
\text { the piloting process }\end{array}$ & $\begin{array}{l}\text { Collecting written reviews and } \\
\text { artefacts from schools }\end{array}$ \\
\hline 01-28.06.2019 & Interpretation & $\begin{array}{l}\text { Expert-coaches are reviewing the } \\
\text { written reports to start analysis of } \\
\text { piloting results, make comparison, } \\
\text { identify risks and benefits }\end{array}$ \\
\hline
\end{tabular}

\section{Results}

Answer to the first research question: To what extent did the schools succeed in implementing the teacher competence management model?

Based on the instructions given at the start of the piloting, school teams linked teacher assessment results with further planning for competence development and thematically focused it around the goal that was set last semester. Some school teams did an additional independent teacher assessment round, mostly by conducting lesson observations, analysed the results with the help of the rubrics showing descriptions of teacher performance level and compared their assessment results with assessment results made by expert-coaches. Additionally, each school had an assigned expert-coach to guide the school teams on how to work with the rubrics and generally help through the piloting process. All schools that continued the piloting have made plans for how to continue the competence development (phase 4) in next school year. School teams used different teacher support materials thematically linked to their goal.

School teams formed different types of collaboration forms, for example, working groups in different forms, daily, weekly or bi-weekly meetings etc. Some working groups had assigned teachers who took a leader's role. In two schools (08_Z and 04_S) all teachers were involved. In school 06_P in weekly school meetings all teachers were introduced with the piloting progress.

School 01_V, after being introduced to the instructions of competence development, opted out from continuing their participation. Stated reasons were that this activity is too time consuming for them and that they have other priorities at the moment. One school did not submit a full report (see table 5). Two schools prepared individual development plans for participating teachers, the results of these activities are described in next paragraphs. 
Table 5. Summary of written school reports according to proposed criteria

\begin{tabular}{|c|c|c|c|c|c|}
\hline School & $\begin{array}{l}\text { Assessment } \\
\text { result }\end{array}$ & $\begin{array}{l}\text { Description } \\
\text { of } \\
\text { development } \\
\text { needs }\end{array}$ & $\begin{array}{c}\text { Development } \\
\text { plan }\end{array}$ & $\begin{array}{l}\text { Solutions } \\
\text { for de- } \\
\text { velopment }\end{array}$ & $\begin{array}{l}\text { Realization } \\
\text { of the plan }\end{array}$ \\
\hline 06_P & $\begin{array}{l}\text { Familiarized } \\
\text { with the results }\end{array}$ & Formulated & $\begin{array}{c}\text { Yes } \\
\text { (electronical) }\end{array}$ & $\begin{array}{l}\text { Made } \\
\text { a plan }\end{array}$ & $\begin{array}{l}\text { Individual } \\
\text { lesson } \\
\text { observation }\end{array}$ \\
\hline 05_R & $\begin{array}{l}\text { Familiarized } \\
\text { with the results }\end{array}$ & Formulated & Yes & $\begin{array}{l}\text { Made } \\
\text { a plan }\end{array}$ & $\begin{array}{l}\text { Collaborative } \\
\text { lesson } \\
\text { observation }\end{array}$ \\
\hline 03_T & $\begin{array}{l}\text { Familiarized } \\
\text { with the results }\end{array}$ & - & $\begin{array}{c}\text { Yes } \\
\text { (electronical) }\end{array}$ & $\begin{array}{l}\text { Made } \\
\text { a plan }\end{array}$ & $\begin{array}{l}\text { Teams were } \\
\text { formed, } \\
\text { collaborative } \\
\text { lesson } \\
\text { observations }\end{array}$ \\
\hline 08_Z & $\begin{array}{l}\text { Familiarized } \\
\text { with the results }\end{array}$ & - & $\begin{array}{c}\text { Yes } \\
\text { (electronical) }\end{array}$ & $\begin{array}{l}\text { Made } \\
\text { a plan }\end{array}$ & $\begin{array}{l}\text { Collaborative } \\
\text { lesson } \\
\text { observation }\end{array}$ \\
\hline 04_S & $\begin{array}{l}\text { Familiarized } \\
\text { with the results }\end{array}$ & Formulated & $\begin{array}{c}\text { Yes } \\
\text { (electronical) }\end{array}$ & $\begin{array}{l}\text { Made } \\
\text { a plan }\end{array}$ & $\begin{array}{l}\text { Collaborative } \\
\text { lesson } \\
\text { observation }\end{array}$ \\
\hline 07_N* & $\begin{array}{l}\text { Familiarized } \\
\text { with the results }\end{array}$ & Formulated & Yes & $\begin{array}{l}\text { Made } \\
\text { a plan }\end{array}$ & Made a plan \\
\hline $02 \_U$ & $\begin{array}{l}\text { Familiarized } \\
\text { with the results }\end{array}$ & Formulated & $\begin{array}{c}\text { Yes } \\
\text { (electronical) }\end{array}$ & $\begin{array}{l}\text { Made } \\
\text { a plan }\end{array}$ & $\begin{array}{l}\text { Collaborative } \\
\text { lesson } \\
\text { observation }\end{array}$ \\
\hline $01 \_V^{* * *}$ & $\begin{array}{l}\text { Familiarized } \\
\text { with the results }\end{array}$ & - & - & - & - \\
\hline
\end{tabular}

*Full report was not submitted

** The school stopped participation in piloting

Answer to the second research question: What are the best practices done in schools when piloting the teacher competence management model?

To answer to the second research question, two school cases will be shortly described. The two cases showed the most progress regarding the model's fourth phase.

\section{School 06_P}

This school is a high school with grades first to $12^{\text {th }}$ with approximately 550 students, 59 teachers, located in one of the nine largest cities in the country, also called republic cities. The goal set in this school was that students acquire self-directed learning. The school is struggling with an aging workforce that is being replaced by a relatively young work 
force - teachers with novice experience. The school leadership team decided to focus on novice teachers during the piloting. The school can be characterized as open to innovations and the school principal has a vision for modernizing the school's learning environment.

In the piloting four school leaders actively participated - the principal and three assistant principals. This leadership team were involved in all activities proposed by the expert-coaches and related to teacher competence assessment and development. They purposefully and with great interest realized the activities and recorded proof of all actions that they took during the piloting. At the beginning they planned to involve six teachers, but in the process more teachers were involved (exact number was not given in the report). Additionally, they informed all teachers about the piloting process in weekly meetings. Competence assessment results are collected about 20 teachers from this school.

School leaders first familiarized with the teacher assessment results, student learning results and the instruction. They planned the necessary actions based on the data, then introduced their plan to participating teachers. Teachers had one week to analyse, reflect about the plan, discuss it together and give feedback and suggestions about it. Two school leaders did teacher lesson observation, by using the given rubric. After the lesson observation, the principal had an individual discussion with the teacher and the expert-coach where they identified one main aspect of the teaching practice that should be improved and formed the basis for teacher's individual development plan. Each teacher set a task that should be done until the end of the semester. Involved teachers formed learning groups depending on their subject areas and who work with the same grades. In these groups, teachers created new classroom assignments for students and other activities supporting student self-directed learning in one selected class in a four-week period. When setting a goal and planning activities, the school leadership team is strictly gradual, that is, the goal is divided into specific, measurable smaller steps and deadlines.

However, this school struggled with getting the school principal and assistant principals to be involved more greatly due to lack of time. Also, the team was not sure about their actual progress because one semester is too short to determine if changes are actually happening. For the next semester, the school team plans to follow each teachers' development path more carefully.

Lastly, this school team shared their planned activities and weekly progress to all other colleagues thus spanning collaboration in the whole school; and pointed out that this collaboration has changed their understanding and ways of thinking, and made their activities more purposeful and focused on their goal. 


\section{School 04_S.}

This school is located in a rural area, it is a basic school with grades one to nine, with approximately 200 students and 24 teachers.

The school goal can be divided into two parts. For teachers the goal was to introduce four basic elements in the student learning process student learning goal, meaningful tasks for students, self-directed learning and development-oriented feedback for students. For students the goal was to introduce tools for assessing growth dynamic of their own self-directed learning. The tools would be used by students themselves for assessing their growth.

The school is open to innovations, they set clearly defined goals. The school leadership team is investing in their teachers and also implementing individual discussions with teachers.

In the piloting, the principal and assistant principal were involved, later the leadership team expanded to three people. They showed motivation to be involved both in data-based goal setting and in teacher competence assessment.

This school team adjusted the lesson observation sheet and planned to do lesson observations four times for each involved teacher. Additionally, an electronic data base for lesson observation results was created compiling information about the goals and the criteria accordingly. Similarly, as in school 06_P, each lesson observation was followed by an individual discussion where the teacher reflected about the weakest points in the lesson and set a goal based on that. Until the next lesson observation, the teacher aims to reach the goal that was set. School team did activities such as watching and analysing video recordings of lesson examples, modelled new lesson activities, lesson observation in their school and in two other partner schools.

At the end of this spring semester, teachers set individual goals for their competence development. Additionally, each teacher has a final individual discussion with a school leader. Not all teachers in the team are ready to analyse their own performance, some teachers perceived their individual competence development planning as "just another duty" and not as a possibility for growth. Similarly, as school 06_P, one semester is too short to determine if the activities have led to actual progress. In next semester teachers will plan their individual development plans based on data from lesson observations and will also plan how to reach their development goals within one semester. The school team also plans to create a teacher learning group. 
Answer to the $3^{\text {rd }}$ research question: What are the main challenges for schools and expert-coaches when piloting the introduction of the model into school practice?

School teams express the need for more support from expert-coaches or at least points out to the lack of sufficient support from them. There is a need for more time dedicated to learning as a way to bring in a more unified understanding about the model in the school and not only in the school leaders' level. For example, in the case of school 06_P in each discussion five to six school leaders were involved. The shared experience from pilot schools emphasises the need for high involvement of the school principal and his/her understanding of what it means to plan and follow through a teacher's individual competence development plan. For example, in school 03_T the principal delegated responsibility of the piloting to teachers. Another challenge is to guide school teams in how to use teacher assessment rubrics, teachers and school leaders still interpret the rubrics and teacher performance differently than expert-coaches.

Setting school goals, cascading the goals to teacher individual level, staff development is the responsibility of the school leadership team. As part of the piloting, school leaders were required to be ready to collaborate, go deeper into teacher competence development, invest into teacher growth. According to the data obtained, participating schools with a motivated leadership team showed better results, and the role of the principal appears to be the most important. At school 01_V, which stopped participating in the piloting, only one deputy principal was initially involved. School 07_N does not have a strong leadership team ready to collaborate with the principal. In school 02_U, during the piloting, there was a change of staff working in the school leadership team, with the main responsibility being delegated to one of the assistant principals.

The piloting process shows various experience regarding number of involved teachers. In this stage of the piloting, it was school teams' free choice to do such competence management. In the future it is planned that a school involves all teachers in their competence assessment and development. The process of piloting was affected by different factors size of the school, number of involved staff from the leadership team and number of involved teachers, type of school goals. We don't have clear evidence showing if implementing the model would be more effective when all teachers are involved or only several groups of teachers. The school goals can be specifically focused on learning results of selected grade level students. This may help gain greater impact of improvements and more focused teacher collaboration and, in the long term, to follow the impact of teachers' competence development on student learning results. 
A positive trend is that the pilot schools are starting to plan their teacher development that is linked to the topical school goals. Schools are organizing teacher learning groups, thus gaining a joint understanding of the necessary changes. However, it is important that the introduction of new knowledge and skills in the everyday practice of teachers is happening in a way that it has more impact on their classroom practice (Lipowsky \& Rzejak 2012), thus a positive impact on student learning results. This is accomplishable through lesson observation, analysing the results and giving feedback to teachers, done by the leadership team or by teachers themselves. In doing appropriate lesson observation and analysis, appropriate criteria and rubrics are important. Schools received these together with the teacher actual profiles in the beginning of the piloting. From the consultations between school leadership teams and expert-coaches, it is evident that despite the high level of detail in the rubric describing levels and criteria, every school leader or teacher, without previous preparation and training, interpret teacher performance in the lesson differently. It can be discussed if this is due to the tradition that teachers have been evaluated summatively and not for development purposed. For example, in school 08_Z, school leadership team reported that teachers showed improvement of two levels higher, that have to be checked by expert-coaches. A solution for such situations would be to conduct joint lesson observations with expert-coaches and school leaders where they agree about the criteria and how to detect it; to have training for school leaders on how to analyse observed lessons. More experienced teachers could also be trained to do lesson analysis as a way to increase their capacity to give support to other teachers. The rubric should also be improved and adjusted to be more understandable for teachers and school leaders and used as self-assessment tool. Further research is needed for determining how such activities may strengthen the school capacity to develop teacher competence.

When compiling the results on how teacher professional development is being planned, we can conclude that it is not personalized enough, which is one of the competence management model's key elements. Only in two schools the involved teams set up teacher personalized development plans. In other schools, the teams don't take into consideration that teacher performance and learning needs differ, which can be seen from their actual profiles. There are schools, that leave it to the teachers themselves to set their individual goals, but the teachers lack the necessary skills or motivation to do it objectively. For example, in school 03_T, the principal received the assessment results (the actual profiles) from expert-coaches and gave the them to each teacher expecting that teachers will be able to define their own development priorities. The leadership team delegated to the high performing teachers to lead other teacher groups, but it was not discussed 
with these teacher team leaders what are the other teachers' learning needs. As well as the competence development of these teachers were not planned.

Joint seminars and written instructions for school leaders for further activities are not enough. The school teams expressed that having an expert-coach available for consultation in the school is an effective way of support. This is indicated by school 04_2, which would had reached better piloting results if collaboration with the expert-coach had been more active. Whereas in school 06_P, the combination of greater investment and interest from both leadership team and expert-coach proved to be decisive for the school leadership team's growth that contributed to a successful piloting of the model.

\section{Conclusions}

The best practices from the pilot schools show that the teacher competence management model can be implemented into school practice if the school is open to innovations and if the school leadership team is investing in teachers and generally interested in supporting teacher growth. On the other hand, the piloting results show activities done by the school leaders that indicate a lack of understanding on how to develop human resources. This has been indicated by previous research showing that school principals in Latvia do not use human resource management techniques systematically as they lack necessary skills and require special training for that (Daiktere, 2012). It is necessary to continue researching what are the current practices of school leaders and their effect on teacher practice and growth and on student learning results.

It should be taken into account that school leaders contribute to student learning through their influence on other people or features of their school's organizational features (Hallinger \& Heck, 1998). The pilot schools set goals related to student self-directed learning (or self-regulated learning) which is in line with what has been pointed out as one of the cornerstones of school effectiveness (Scheerens, Luyten, Steen, \& Luyten-de Thouars, 2007).

The piloting of the teacher competence management model will continue in the autumn semester, 2019 in order to gain more insight in the model's and its teacher competence assessment instruments' applicability for school practice. It is still needed to explore the different factors that hinder or support the model's implementation into school practice in Latvia. Additional evidence is needed to determine if the used teacher assessment approaches (teacher test and lesson observation) can be used in schools independently as teacher self-assessment tools. Our experience from this piloting semester show that school team interpret the teacher assessment results differently. 


\section{Acknowledgements}

This research is supported by the ERDF research project "The Application of Principles for Information System Modelling to Structured and Goal-Oriented Competence Management", agreement No. 1.1.1.1/16/A/252.

\section{References}

Bērtule. D., Dudareva, I., Namsone, N., Čakāne, L., Butkēviča., A. (2019). Framework of Teacher Performance Assessment to Support Teaching $21^{\text {st }}$ Century Skills. Proceedings of the $13^{\text {th }}$ annual International Technology, Education and Development Conference INTED 2019 Valencia, Spain Valencia, 11-13.03.2019.

Bluma, D., \& Daiktere, I. (2016). Latvia: School principals and leadership research in Latvia. In A Decade of Research on School Principals (pp. 137-160). Springer, Cham.

Butkēviča, A. (2018). Goal Management \& Teacher Competence Development in Schools. In Daniela, L. (Eds.) Innovations, Technologies and Research in Education (pp. 199-214). Cambridge Scholars Publishing. Presented at the ATEE Spring Conference in Riga, Latvia, May 12-13, 2017.

Butkēviča, A., Dudareva, I., Namsone, D., Zandbergs, U., Čakāne, L., Bērtule. D. (2019). Designing and Piloting Online Tests as Part of a Teacher Competence Assessment. SOCIETY. INTEGRATION. EDUCATION. Proceedings of the International Scientific Conference, Volume V (pp. 333-343) Presented in Rezekne, Latvia, May 24. 2019. http://dx.doi.org/10.17770/sie2019vol5.3846.

Butkēviča, A., Zandbergs, U., Namsone, D., \& Brike, S. (2018). Exploring the Input of Competence Assessment to Goal-setting in Various Types of Organizations. SOCIETY. INTEGRATION. EDUCATION. Proceedings of the International Scientific Conference, Volume VI (pp. 130-141). Presented in Rezekne, Latvia, May 25-26, 2018. http:// dx.doi.org/10.17770/sie2018vol1.3280.

Care, E., Griffin, P., \& Wilson, M. (Eds.). (2017). Assessment and teaching of $21^{\text {st }}$ century skills: research and applications. Springer.

Daiktere, I. (2012). Vispārizglītojošās skolas direktora loma skolas kultūras pilnveidošanā. Dissertation for obtaining doctoral degree in education management, University of Latvia.

Daniela, L., Strods, R., Rubene, Z., \& Kalnina, S. (2018). Student-teachers' Ability to Implement Competency Approach: The Case of the University of Latvia. In The Future of Innovation and Technology in Education: Policies and Practices for Teaching and Learning Excellence (pp. 221-235). Emerald Publishing Limited.

France, I., Namsone, D. and Cakane, L. (2015). What Research Shows about Mathematics Teachers' Learning Needs: Experience from Latvia. In SOCIETY. INTEGRATION. EDUCATION. Proceedings of the International Scientific Conference (Vol. 2, pp. 45-55).

Geske, A., \& Rečs, N. (2019). The Impact of Headmaster's Leadership Practice on the Formation of a Professional Learning Community at School. In Proceedings of the International Scientific Conference SOCIETY. INTEGRATION. EDUCATION. Volume II, p. 90-105. http://dx.doi.org/10.17770/sie2019vol2.3816.

Hallinger, P., \& Heck, R. H. (1998). Exploring the principal's contribution to school effectiveness: 1980-1995. School effectiveness and school improvement, 9(2), 157-191. 
Ivanova, I., \& Skara-Mincāne, R. (2016). Development of professional identity during teacher's practice. Procedia-Social and Behavioral Sciences, 232, 529-536.

Jermolajeva, J., Bogdanova, T., \& Silchenkova, S. (2018). Social Behavior of Schoolteachers of Latvia and Russia in the Structure of Teacher Professional Identity. Economics and Culture, 15(2), 43-54.

Kunter, M., Klusmann, U., Baumert, J., Richter, D., Voss, T., \& Hachfeld, A. (2013). Professional competence of teachers: Effects on instructional quality and student development. Journal of Educational Psychology, 105(3), 805.

Lipowsky, F., \& Rzejak, D. (2012). Lehrerinnen und Lehrer als Lerner - Wann gelingt der Rollentausch? Merkmale und Wirkungen effektiver Lehrerfortbildungen. Schulpädagogik heute, 5(3), 1-17.

Namsone, D. (Scientific Editor) (2018). Learning for Competence (Mācišanās lietpratībai) [Monograph]. Riga: University of Latvia Academic Publishing. https://doi. org $/ 10.22364 / \mathrm{ml} .2018$.

Namsone, D., \& Čakāne, L. (2018). A Collaborative Classroom-Based Teacher Professional Learning Model. In Yeo J., Teo T., Tang K. S. (eds.) Science Education Research and Practice in Asia-Pacific and Beyond (pp. 177-195). Singapore, Springer Nature. DOI: https://doi.org/10.1007/978-981-10-5149-4_13

OECD. (2015). Enabling the Next Production Revolution. (For Official Use).

OECD. (2019). TALIS 2018 Results (Volume I): Teachers and School Leaders as Lifelong Learners, TALIS. OECD Publishing, Paris. https://doi.org/10.1787/1d0bc92a-en.

Saavedra, A. R., \& Opfer, V. D. (2012). Learning $21^{\text {st }}$-century skills requires $21^{\text {st-century }}$ teaching. Phi Delta Kappan, 94(2), 8-13.

Scheerens, J. (2016). Educational effectiveness and ineffectiveness. A critical review of the knowledge base, 389.

Scheerens, J., Luyten, H., Steen, R., \& Luyten-de Thouars, Y. (2007). Review and meta-analyses of school and teaching effectiveness. Enschede: Department of Educational Organisation and Management, University of Twente.

Skola2030. (2017). Izglītība mūsdienīgai lietpratībai: mācību satura un pieejas apraksts (Education for contemporary competence: description of curricula and approach) [reform document for public consultation]. Retrieved from: https://docs.wixstatic.com/ ugd/3e1e8c_0b2ac53576544b70a2b689edcfbef010.pdf.

Volkinsteine, J. and Namsone, D. (2016). Acquisition of student scientific inquiry skills: centralized examination results in chemistry. In SOCIETY. INTEGRATION. EDUCATION. Proceedings of the International Scientific Conference (Vol. 2, pp. 373-386).

Zandbergs, U., Namsone, D., \& Brik̦e, S., Butkēviča, A. (2018). Model of Linking Organization Goals to Employee Competence Management for Formal and Non-formal Education Providers. $13^{\text {th }}$ International Baltic Conference on Databases and Information Systems, July 1-4, 2018, Trakai, Lithuania. 